\title{
Seasoned Equity Offerings as Technical Market Anomalies: Long-Term Temporal Trading Functionalities
}

\author{
Vasiliki A. Basdekidou ${ }^{1}$ \\ ${ }^{1}$ SRFA Aristotle University of Thessaloniki, Greece \\ Correspondence: Vasiliki A. Basdekidou, Special Research Fund Account (ELKE), Aristotle University of \\ Thessaloniki, Greece. Tel: 30-697-277-5475. E-mail: Vasiliki.Basdekidou@ gmail.com
}

Received: August 3, 2016

Accepted: November 30, $2016 \quad$ Online Published: December 14, 2016

doi:10.5539/ijef.v9n1p96

URL: http://dx.doi.org/10.5539/ijef.v9n1p96

\begin{abstract}
The main goal of this paper is to approach the Seasoned Equity Offerings (SEO) trading opportunities as technical market anomalies and under the prism of a number of temporal (time-based) long-term trading functionalities (long-term TTF) introduced for the first time in corporate finance literature. The long-term is defined, for the purposes of this paper, as the 3-year time period, traded usually with daily, weekly and monthly time-frames. Trading is a temporal (i.e. time-based) historical living system with a number of functions, like: SEO, IPO, stock (instrument) price action Gaps, Breakouts, etc. In this domain, a number of warning long-term and short-term dynamics timing functionalities is available, like: candlestick patterns breaks, price action patterns pivotal-lines breaks, on open gup-ups (ooGUp), on open gup-downs (ooGDn), morning breakouts (mB), etc. All these time-based functionalities are regarded as $2^{\text {nd }}$ level functions (i.e. functions of functions; because of the timing involved) with great trading opportunities, and they are defined -for the first time in the corporate finance literature- by this paper as temporal (timing) trading functionalities. In particular, the SEOs with the embedded long-term TTF functionalities are great trading opportunities for the institutions, the individual (non-commercial) market investors, the swing traders, and the speculators. Data analysis shows that during the seasoned equity offerings time, shareowners significantly increase their share-holding, including offerings that would be classified as overpriced at that time; hence, the involved trading volatility is increased resulting in great trading and profit opportunities. This paper contributes to corporate finance literature by examining the SEOs functions and define and document their inherit TTF functionalities. For this purpose, four categories of share-holders are regarded: The long-term institution \& non-commercial traders (investors), the swing momentary institution traders (institutions), the short-term non-commercial traders (speculators) and the intraday non-commercial traders (speculators). Paper concludes that, in SEO/long-term TTF trading, apart from the insiders, the swing traders (usually the smart-money and the institutions) are more benefited, at the expense of momentary short-term and intraday speculators, while the long-term investors are not affected by the SEO offerings.
\end{abstract}

Keywords: equity issue timing, corporate ownership, liquidity, market timing, seasoned equity offerings (SEO), temporal (timing) trading functionalities (TTF), technical market anomalies

\section{Introduction}

The main goal of this paper is to approach the Seasoned Equity Offerings (SEO), as technical market anomalies and trading opportunities, under the prism of a number of temporal (time-based) long-term trading functionalities (long-term TTF) introduced for the first time in corporate finance literature. The long-term is defined, for the purposes of this paper, as the 3-year time period, traded usually with daily, weekly and monthly time-frames.

\subsection{Problem Introduction}

Trading is regarded as a temporal historical living system (Styliadis, 2007; Styliadis \& Vassilakopoulos, 2005) with a number of time-based company initiatives operating as trading functions. Historically, trading company initiatives is undertaken by insiders and technical analysis speculators without semantic temporal influence in their plans and strategies. In these initiatives, the issuing company allocates securities (and particularly "shares" and not other securities like bonds, warrants, etc.) to new owners resulting in company's outstanding capital growing. One of these company initiatives is the SEO which, like the IPO initiative (Choie, 2016), has a great 
temporal (timing) trading functionality (Hovakimian \& Hu, 2016; Demiralp et al., 2011), resulting in excellent profit \& wealth growth opportunities (Ogden \& Wu, 2013; Basdekidou, 2015). In this domain, economics and finance literature reasoning that the companies "time" their SEOs and IPOs to months of relatively high stock prices, mainly because the CEOs and officers think that the prices of the shares (company stocks) will probably be overbought at such "times" (an encapsulated TTF functionality).

The observed mispricing, as a typical technical market anomaly, concealed such as trading timing and could be regarded as the result of the lack of any available TTF information (for the investors, traders, institutions and speculators) for the embedded time-based behavioral biases dominant in securities (equities), Forex and option markets (Basdekidou, 2016a; Basdekidou, 2016b; Basdekidou \& Styliadou, 2017). The reason that long-term investors (institutions) could buy overbought shares in SEOs/TTF is the same, in regard also with Edelen, Ince, and Kadlec (2015), who provide evidence that long-term investors, traders and speculators prefer to purchase shares classified as overbought (momentum trading psychology) based on a number of classical equities-trading strategies ("trend-follow" trading, but without any TTF functionality in this case).

Corporate financing approach emphasizes that disengagement of holding and domination has as a result the clash of interest between outside shareowners, CEOs, and governors (Jensen, 1986). In this domain, the literature reasoning is that big corporate shareowners (not interested in short-term trading; not using TTF functionalities in their trading plans) can alleviate such things as clashes by positioning, observing and controlling CEOs and governors through the SEC reports (Hartzell \& Starks, 2003; Myers \& Majluf, 1984).

Trading (Myers \& Majluf, 1984) and trading timing (Baker \& Wurgler, 2002) approaches of economics and finance try to clarify such attitude, assuming that the shares trading decisions (i.e. open/close positions; lot trade size, etc.) are formed for the regard of old non-speculative shareowners (investors), who adequately take profit from SEO shares just as a consequence of right-timing SEO initiatives/issues based on long-term (year) time trading functionalities (SEO/long-term TTF) and not as a result of a well-designed, based on long-term TTF, trading strategy. The current paper agrees that the data are consistent and produce profit with such expectations, as far as the timing of the company's SEO initiatives is regarded as a long-term TTF functionality.

\subsection{Problem Importance Exploration}

In the situation of equities and non-equities SEO "timing" (stocks, options, Forex, etc.), Cesari, Espenlaub, Khurshed, and Simkovic (2012) argues on the effects of share-holding and stock liquidation on the SEO/TTF timing transactions of open and close position (i.e. "buy" in case of a short position; and "sell" in case of a long position), but no more details for long-term TTF functionalities were given; and Demiralp, D’Mello, Schlingemann, and Subramaniam (2011) state that old-issue share returns and passive trading, are both strongly connected with the coexisting old-issue changes in corporate holding for a time period up to 3 years after the SEO/TTF time. This 3-year period is regarded as too big, even for the "buy-and-hold" investors, for nowadays swing and volatile securities markets (leveraged 3x ETFs; Gold, Silver, WTI Oil, and Natural Gas ETNs; etc.).

In this article, the author concludes that her results are persistent with the control acting of long-term passive-trading investors. Also, in this case the TTF functionalities were not discussed. Furthermore, Hao (2014) states that companies with higher short-term non-commercial shareowners (speculators) enjoy more negative atypical results at the report release (TTF timing) of SEOs and concludes that momentary corporate shareowners and speculators are not prompted to control the usage of the lifted trading capital and profit (Choie, 2016; Hovakimian \& $\mathrm{Hu}, 2016)$.

\subsection{Relevant Scholarship Description}

The current article is relevant to some other articles that investigate corporate share-holding under the prism of the SEO/TTF timing. In this frame, some articles (Choie, 2016; Markoulis \& Neofytou, 2016) targeted on the information asset and stock-taking intelligence of corporate investors, while others (Hao, 2014; Baker, Stein, \& Wurgler, 2003) targeted the trading strategies and plans, but in both cases no TTF information was given. Gibson, Safieddine, and Sonti (2004) report that seasoned equity and option SEO initiatives, with the bigger boost in corporate share-holding, are detected between the (relative to SEO/TTF, SEO timing) quarters -1 and +1 ; these long-term investors reported that their positions outperform in the subsequent the SEO issue year and qualify this outperform to their competitive convenience asset position. Chemmanur, $\mathrm{He}$, and $\mathrm{Hu}$ (2009) find that long-term passive-trading investors (as opposed to non-commercial short-term investors and traders) are likely to experience bigger share positions in SEOs hoping on better results (profit) and their transactions somewhat greatly exceed a (even a well designed) passive "buy-and-hold" trading plan by the share-holding investors (Nguyen \& Tran, 2016; Basdekidou, 2016a; Basdekidou \& Styliadou, 2017). 
In accordance to the above situation, Edelen, Ince, and Kadlec (2015), examined corporate trading and securities return divergences, and discovered that corporate firms prefer to purchase shares categorized as overbought and this is regarded as a non-positive association (i.e. relationship functionality) between corporate open-position and future trading (close-position) result. In opposition to these articles that spotlight on whether long-term investors and old-shareowners are better-informed (i.e. insiders functionality), the current research article targets on the dominant relationship and the underlined trading functionalities between the corporate shareowners and the CEO/managers (Basdekidou, 2016b).

Alti and Sulaeman (2012) also expressed a disaggrement to these articles, by pointing out how company SEO issuing initiative is influenced by corporate and non-commercial trading. In their paper, they support the position that strong securities trading results and profit trading trigger equity derivation only if the later is connected with a great pre-issue corporate investor demand, as it is regarded to be consistent with the new corporate holdings (swing momentary traders). Alti and Sulaeman also clarify their results as logical and dependable with SEO initiatives using the corporate investor demand as a gauge of the market's interest in the company's equity SEO initiative.

In this domain, the main target of the current article is disparate. Actually, I investigate whether old shareowners (as long-term investors), gain profit from the SEO/TTF timing. It is notable that, the results obtained do not depend on the supposition and conclusion that SEOs/governors are gauged to sell overbought shares for the interest and profit of such kind of shareowners (corporate investors as opposed to non-commercial momentary speculators).

\subsection{Paper's Structure}

The rest of the article is organized as follows: Section 2 ("Share-holding \& Trading Data") describes the share-holding data as the corporate share-holding variables; Section 3 ("Temporal (timing) Trading Functionality") documents the introduced TTF term by examining the relation between SEO timing and institutional \& non-commercial share purchases, as well as the impact of corporate \& non-commercial holdings on SEO timing; Finally, Section 4 ("Conclusions \& Discussion") summarizes the conclusions and discusses paper's innovations and contributions.

\section{Share-holding \& Trading Data (Institutions and Non-Commercial Traders)}

For the current paper, the share-holding information, the changes in insider holdings \& some sample profit/losses trading data (1990-2016) - used in this paper as the share-holding \& profit variables- came from many resources. The Barron's information databases and sources, a Wall Street Journal affiliate (Barron's, 2016); the StockCharts.com initiative; the Securities \& Exchange Commission/SEC notices, releases \& announcements; the Commitments of Traders (CoT) / CFTC speculative net positions reports; the Yahoo! Finance insiders data feed; the SEC EDGAR database; individual filings at: http://www.sec.gov/cgi-bin/srch-edgar; SEC's Forms 4 (CEO) \& 14a (Directors \& Officers); and the Thomson Financial corporate holdings SEC's Form 13f database, which reports corporate share-holdings and profit/losses on a calendar-quarter base ending in the last day of March, June, September, and December. The United States SEC requires that all commercial investors and traders with a total position more than $\$ 100$ million of securities or equities positions greater than 10,000 shares or positions in individual shares greater than $\$ 200,000$, must report their holdings, using the SEC's Form 13f, quarterly.

In this paper, the above numbers were used to estimate, with an acceptable standard deviation (st. dev.), total corporate securities holdings and position changes (if applicable). Also, the current paper identifies long- and short-term corporate investors, traders and speculators based on their average portfolio "security turnover" (defined as a measure of security liquidity; calculated by dividing the total number of securities traded over a period by the average number of securities outstanding for the same period. Obviously, the higher the "security turnover" number, the more volatile the trading and more opportunities for profit after applying a trading strategy based on long-term TTFs) in the last four quarters (Yan \& Zhang, 2009).

Additionally, for each of the above four (4) quarters, the traders involved in SEO were sorted into four categories ("quadrants") according to their temporal (time-based) corporate holdings as the percentage of total shares outstanding at the end of each of these quarters. In the first category, I placed the institutions ranked in the bottom "quadrant" after having the lowest "security turnover"; they are classified as Long-term corporate passive investors (LT share-holding Investors) (Table 1). In the second category, I placed the institutions ranked in the top "quadrant" after having the highest "security turnover"; they are classified as Momentary corporate swing-trading investors (swing ST institution share-holding Traders) (Table 1). Then, the rest group is divided into two equal categories (third \& fourth "quadrant"). In the third category, I placed the individual traders involved in swing SEO trading (ST non-commercial share-holding Speculators) (Table 1). Finally, in the forth 
category the detected intraday individual traders were placed (Intraday non-commercial share-holding Speculators) (Table 1).

The result is an unbalanced panel, covering the sample time period from January $1^{\text {st }} 2000$ to June $30^{\text {th }} 2016$, with more than 100,000 Non-SEO and more than 3,100 SEO observations. The sample period starts from 2000 because from this year the data (share-holding, transaction, etc.) are available in a digital format with a relatively low cost.

While quarterly data allow me better and more accurately to associate share-holding changes with SEO/TTF, time longer (annual) results are presented for two reasons. First, because they help me to understand how unusual the changes in ownership at the time of SEO are; and second, the annual (fiscal year) long-term data provide firmness as well as flexibility with any following throwbacks, which are estimated using (fiscal year) long-term annual data. The statistics for the sample time period are presented in the following Table 1, which displays the summary numbers of SEO initiatives and Non-SEO initiatives from $1^{\text {st }}$ January 2000 to $30^{\text {th }}$ June 2016 (Seasoned equity offerings are obtained from SEC/SDC).

Table 1. Sample share-holding statistics

\begin{tabular}{|c|c|c|c|c|c|c|c|c|c|}
\hline & \multicolumn{3}{|c|}{ Equity SEO initiatives } & \multicolumn{4}{|c|}{ Non-SEO initiatives } & \multirow[b]{2}{*}{ St.dev. } & \multirow[b]{2}{*}{ Differences* } \\
\hline & Obs. & Mean & Median & St.dev. & Obs. & Mean & Median & & \\
\hline \multicolumn{10}{|l|}{ A. Firm characteristics } \\
\hline Size & 3105 & 4.54 & 4.54 & 1.92 & 100,005 & 4.70 & 4.87 & 2.05 & -0.16 \\
\hline Return & 3105 & 0.50 & 0.25 & 1.25 & 100,005 & 0.15 & 0.04 & 0.87 & 0.35 \\
\hline Market-to-book & 3105 & 2.31 & 1.82 & 1.59 & 100,005 & 1.69 & 1.25 & 1.22 & 0.62 \\
\hline Total share-holding & 3105 & 51.62 & 49.88 & 26.50 & 100,005 & 35.04 & 29.59 & 26.92 & 16.58 \\
\hline LT share-holding Investors & 3105 & 8.68 & 6.92 & 7.26 & 100,005 & 9.55 & 7.47 & 9.72 & -0.87 \\
\hline Swing ST Traders & 3105 & 12.27 & 10.46 & 10.48 & 100,005 & 10.10 & 7.00 & 11.58 & 2.17 \\
\hline ST Speculators & 3105 & 14.70 & 11.41 & 12.54 & 100,005 & 11.35 & 7.57 & 12.30 & 3.35 \\
\hline Intraday Speculators & 3105 & 16.67 & 15.49 & 17.40 & 100,005 & 12.88 & 8.02 & 13.66 & 3.79 \\
\hline \multicolumn{10}{|l|}{ B. Changes in share-holding } \\
\hline Continuing share-holding & 3984 & 5.42 & 3.07 & 8.30 & 100,740 & 0.98 & 0.32 & 5.44 & 4.44 \\
\hline LT Continuing share-holding & 3504 & 1.54 & 0.95 & 2.77 & 100,200 & 0.61 & 0.22 & 2.48 & 0.93 \\
\hline ST Continuing share-holding (Traders \& & & & & & & & & & \\
\hline Speculators) & 3504 & 1.09 & 1.03 & 5.39 & 80,900 & 0.12 & 0.02 & 4.44 & 0.97 \\
\hline \multicolumn{10}{|l|}{ Liquidations } \\
\hline LT liquidations & 2552 & -1.19 & -0.51 & 1.42 & 62,802 & -1.26 & -0.22 & 2.05 & -0.07 \\
\hline ST liquidations (Traders \& Speculators) & 3884 & -4.25 & -3.92 & 4.71 & 77,300 & -4.90 & -2.03 & 6.23 & 0.65 \\
\hline \multicolumn{10}{|l|}{ Initiations } \\
\hline LT initiations (new Investors) & 4223 & 2.31 & 2.57 & 3.03 & 90,009 & 2.04 & 1.35 & 3.69 & 0.27 \\
\hline ST initiations (Traders) & 4196 & 12.42 & 10.83 & 10.02 & 81,770 & 4.77 & 2.33 & 6.06 & 7.65 \\
\hline
\end{tabular}

*Changes significantly different from zero at $5 \%$ level.

Note. Size: The natural Logarithm of Sales;

Return: The Stock return measured over the fiscal year;

Market-to-book: The (total assets - book equity + market equity) / total assets;

LT: The Long-term corporate share-holding (Corporate investors' ownership-period is identified from their portfolio "security turnover" over the last four quarters);

ST: The Momentary corporate share-holding (Corporate investors' ownership-period is identified from their portfolio "security turnover" over the last four quarters);

Continuing share-holding: This term is referred to corporate investors, as shareowners, both at the beginning and at the end of the fiscal year (annual data);

Liquidations: This term is referred to cases where institutions own shares at the beginning of the fiscal year but liquidate their holdings by the end of the fiscal year (annual data);

Initiations: This term is referred to cases where institutions own no shares at the beginning of the fiscal year but establish new positions by the end of the fiscal year (annual data);

Difference: The difference in Means between SEO initiatives and Non-SEO initiatives. Another version of Table 1 sample statistics would support quality interpretations based on the "Medians" (usually used in corporate finance and securities trading literature) rather than the "Means". 


\section{Temporal (timing) Trading Functionalities (TTFs)}

In this section, the innovative term Temporal (timing) Trading Functionality (TTF) is introduced, analyzed and documented.

\subsection{Equity SEO Initiative Timing \& Corporate Share-Holding around Equity SEO Initiatives}

Hovakimian and $\mathrm{Hu}$ (2016) first well examine the arrangement of changes in corporate share-holding around equity SEO initiatives and then (just) present the time-series functionalities of mean Market-to-Book ratios and stock returns for 3 years before and 3 years after the year of equity issue (SEO) without a temporal TTF functionality. Their findings rise for future researchers some questions about the interpretation of SEO timing (i.e. TTF functionalities) reflected in candlestick and price action patterns as attempt and strain to buy oversold and to sell overvalued securities (Choie, 2016; Nguyen \& Tran, 2016; Nickerson, 2016).

\subsection{Corporate Share-Holding around the Equity SEO Initiatives}

Chen, Harford, and Li (2007) and Hao (2014) argue that long-term institutions tend to be passive traders and, therefore, are not interested in the SEO/TTF functionalities. On the other hand, momentary, swing, and intraday trading institutions (and speculators as well) usually have better quality data and therefore tend to trade actively the SEO initiatives to benefit from their own informational convenience asset position. The significant information, gained by Figure 1, is the comparison tests between the share-holdings changes during the indicated period to share-holdings changes in period 0 (i.e. SEO timing).

The results in Figure 1 show that momentary swing trading corporate shareowners, clearly and strongly increment (boost positions) their security position during the year of the SEO; and mainly in the current quarter of the SEO initiative. Actually, these share-holding changes are significantly different from zero. On the other hand, the level of share acquisitions by the long-term passive-trading institution shareowners remains inflated for at least three (3) years after the SEO initiative; whereas the level of withdrawals (liquidations) for the short-term speculators and the swing traders constantly and continuously increases just after the SEO initiative. The results also show that the level of new share-holding position initiations rises in the year and particularly at the current quarter of the SEO initiative (insiders). Figure 1 presents stock's price action chart (rich in candlestick and price action patterns, as long-term TTF warning dynamics trading signals), in a Year time-frame format, from Year -3 to Year +3 relative to the $\mathrm{SEO}$ issue year.

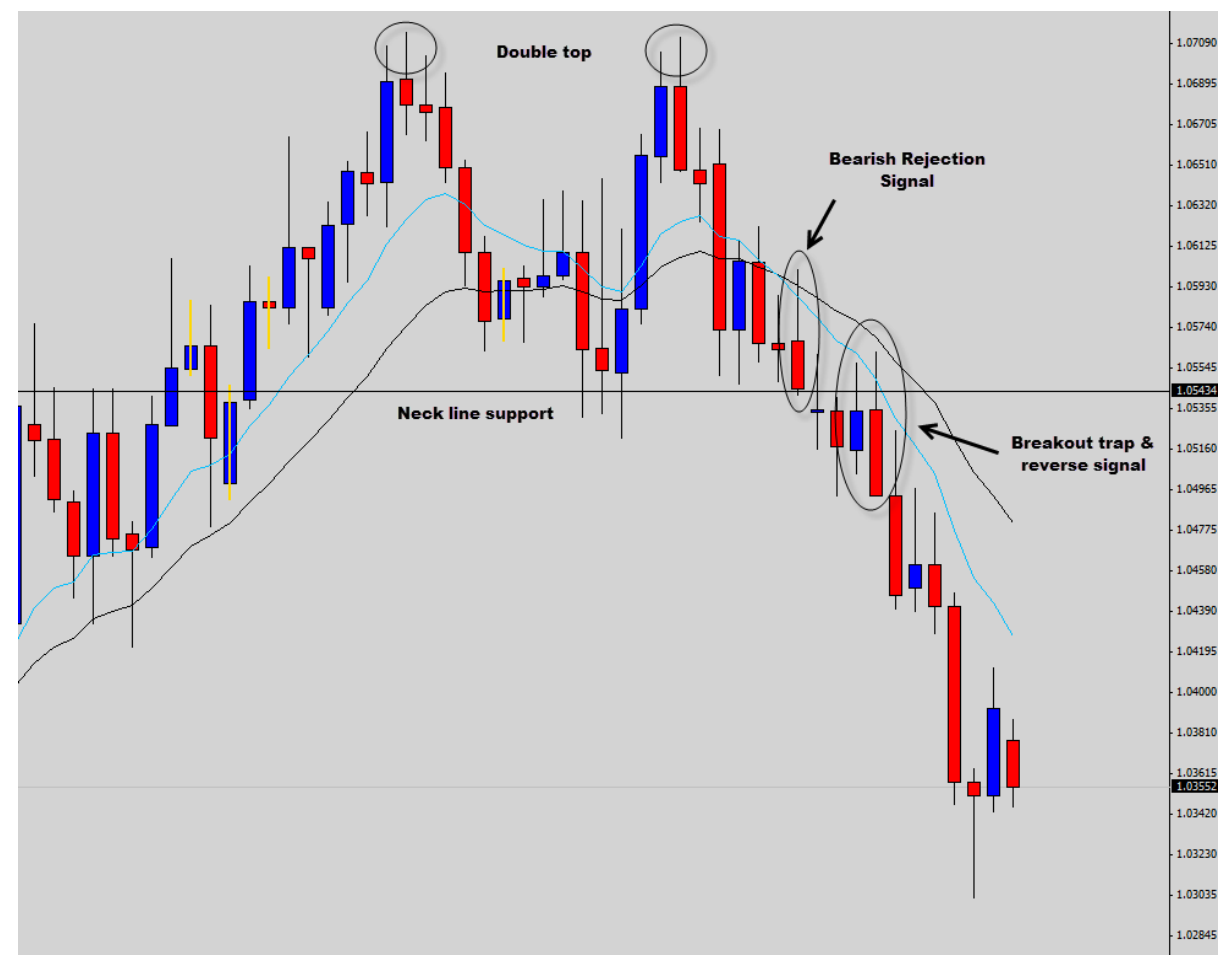

Figure 1. Market timing of equity SEO initiatives (Year time-frame)

Note. Market-to-Book: The price defined as: (total assets - book equity + market equity) / total assets.

Return: The security return measured over the fiscal year. Year (timing) 0: The SEO issuing year (current quarter). 
Following, Table 2 presents the time-series profiles of mean Market-to-Book ratios and Returns of equity SEO initiatives from year -3 to +3 relative to the SEO issue years (Year time-frame: long-term TTF functionality). The changes are statistically significant at $1 \%$ level.

Table 2. The (Year time-frame) time-series profiles of mean market-to-book ratios \& returns

\begin{tabular}{lcccccccccc}
\hline & \multicolumn{1}{c}{ Levels } \\
\hline Year & -3 & -2 & -1 & 0 & 1 & 2 & 3 & -3 to -1 & -1 to 0 & -1 to 3 \\
Market-to-Book & 1.72 & 2.01 & 2.78 & 2.30 & 2.09 & 1.58 & 1.77 & 0.22 & -0.21 & -0.71 \\
Return & 0.36 & 0.32 & 0.22 & 0.55 & 0.32 & 0.09 & 0.15 & 0.42 & -0.11 & -0.52 \\
\hline
\end{tabular}

Note. ${ }^{*}$ Changes significantly different from zero at $1 \%$ level.

Market-to-Book: The price is defined as: (total assets - book equity + market equity) / total assets.

Return: The stock return measured over the fiscal year.

Year (timing) 0: The SEO issuing year (current quarter).

The results in Table 2 show that, similarly to insiders and unlike the long-term corporate shareowners, existing momentary swing trading corporate shareowners sharply increase their share purchases in the year and especially in the current quarter of the SEO initiative (TTF functionality). Then, in the period following the SEO initiative, the level of share purchases by continuing short-term swing trading shareowners drops below the pre-SEO initiative level.

The level of liquidations increases somewhat during the year and the current quarter of the SEO initiative and shows further increase after the SEO initiative, substantially exceeding the pre-SEO initiative level. The results also show that the level of new share-holding position initiations rises in the year and the quarter of the SEO issue and then drops back to the pre-SEO initiative levels.

Overall, these results suggest that the existing long-term institution shareowners act as if they are not concerned about SEO/TTF timing. Furthermore, the fractional share-holding level of existing momentary corporate investors and speculators increases in the SEO quarter, which implies that SEO's fractional allocation to these shareowners exceeds their fractional pre-existing stakes in the firm. This means that existing long-term corporate shareowners do not benefit from SEO timing.

\subsection{The Temporal (Timing) Trading Functionality}

Company initiatives and particular the SEO ones, offer great trading opportunities (leverage, options, CfDs, long/short positions, etc.) for all kind of traders (investors, institutions, insiders, individual non-commercial market investors, and speculators). Trading these initiatives is a time sensitive procedure that requires to have and to obey a strict time-based strategy. So, in trading, the need for a $2^{\text {nd }}$ level timing function of the SEO trading opportunities is obvious.

The innovative term "Temporal (Timing) Trading Functionalities" (TTFs) is defined as an array of temporal functionalities applied to traditional company initiatives like SEO \& IPO, and stock price action patterns like Gaps ("Windows" in technical analysis terminology) and Breakouts. These TTF temporal functionalities are both short-term (popular price action time-frames: [5-minute], [30-minute], [1-hour], [2-hour]) and long-term (popular price action time-frames: [day], [week], [month]); and they could be documented by time-targets in trading securities (stocks, options, futures, Forex, bonds, warrants, etc.) as follows: define swing, momentary \& intraday trading strategies based on specific time-targets; and open/close long/short positions at a specific time-target. These time-targets could be the SEO announcement time and the SEO actual time.

The TTF temporal functionalities operate as great warning dynamics trading signals when they are related to particular candlestick and price action pattern-targets. Following, Table 3 presents a small number of initiatives (functions) and the related warning dynamics temporal (timing) long-term TTF functionalities acting actually as time-based pattern-targets in securities (shares), options, futures, and Forex short-term, swing and intraday trading.

For the TTF-based trading strategies, these long-term pattern-targets operate as warning dynamics signals (w!D signals), awaiting the final confirmation/triggering signal (e.g. candlestick Break; Jesse Livermore's resistance pivotal-line Breakout; Jesse Livermore's support pivotal-line Breakdown) just before the executive order (i.e. Open / Close position). 
Table 3. Company initiatives, fed meetings, reports \& long-term TTF (pattern-targets)

\begin{tabular}{ll} 
Company Initiatives, Fed Meetings, Report & Time-based Pattern-Targets (long-term TTF trading) \\
\hline SEO company initiative & SEO announcement time \& SEO actual time \\
\hline Day Trading & 1-candle Hammer \& inverted Hammer Candlestick Patterns (Hammer; Shooting Stars) \\
Fed/FOMC monetary policy meetings & Price Action Patterns (Head \& Shoulders / Neckline) \\
Fed/FOMC monetary policy meetings & 2-candle Engulfing Candlestick Patterns (Bullish Engulfing; Bearish Engulfing) \\
Fed Members Speeches & Three White Soldiers (after down-trend: Bullish Pattern); Three Black Crows (after \\
& up-trend: Bearish Pattern) \\
Non-Farm Payrolls reports & 3-candle Stars Candlestick Patterns \\
& (after down-trend: Morning Star; after up-trend: Evening Star) \\
API reports for WTI (USO) inventories & 1-cabdle Dojis Candlestick Patterns \\
EIA reports for WTI (USO) inventories & Price Action Patterns (Cups; Uprising Triangles; Head \& Shoulders / Neckline; etc.) \\
\hline
\end{tabular}

Comparative analysis shows that the TTF temporal (year) functionalities better apply to the following four categories of traders:

(1) Long-term Institution Investors ("LT Investors")

(2) Short-term Swing Traders ("ST $T_{1}$ Traders")

(3) Momentary Short-term Traders ("ST $T_{2}$ Speculators")

(4) Intraday Traders ("ST 3 Speculators")

Following, Table 4 presents, in summary, the ownership \% (share-holding position) \& the trading results (profit \%) for these four categories of traders. The data used were those presented in Section 2 "Share-holding \& Trading Data" ( $1^{\text {st }}$ January $2000-30^{\text {th }}$ June 2016).

Table 4. Ownership (\%) \& trading results (\%)

Ownership \& (Share-holding Position \%)

Trading Results (\%)

\begin{tabular}{|c|c|c|c|c|}
\hline & Before SEO date & @ SEO date (time) & After SEO date & Profit \\
\hline Long-term Investors (LT Investors) & $100 \%$ & $81.90 \%)$ & $100 \%$ & $0 \%$ \\
\hline Short-term Swing Traders ( $\mathrm{ST}_{1}$ Traders) & $0 \%$ & $5.10 \%$ & $0 \%$ & $9 \%$ \\
\hline Momentary Short-term Traders ( $\mathrm{ST}_{2}$ Speculators) & $0 \%$ & $8.40 \%$ & $0 \%$ & $-2.5 \%$ \\
\hline Intraday Traders ( $\mathrm{ST}_{3}$ Speculators) & $0 \%$ & $4.60 \%$ & $0 \%$ & $-6.5 \%$ \\
\hline
\end{tabular}

\section{Conclusions \& Discussion}

The main goal of this paper is to approach the seasoned equity offerings (SEO) trading opportunities under the prism of a number of temporal (time-based) long-term trading functionalities (long-term TTF) introduced for the first time in corporate finance literature. The long-term is defined, for the purposes of this paper, as the 3-year time period, traded usually with daily, weekly and monthly time-frames.

The seasoned equity offerings trading functions offer great temporal (i.e. time-based) trading opportunities (i.e. Temporal Trading Functionalities, SEO/TTF: time-based leverage, options, CfDs, Long/Short positions, etc.) for the institutions, the insiders, the individual non-commercial market investors, and the speculators. Data analysis shows that during the SEO time, shareowners significantly increased their share ownership -including offerings that would have been categorized as overpriced during that SEO period- resulting in increasing volatility and trading profit opportunities (Nickerson, 2016).

Due to the fact and in the sense that corporate shareowners can control and restraint CEOs, governors and managers, the SEO/long-term TTF initiatives are expected to be in the interest of such shareowners. According to the corporate finance literature, these sort of shareowners are expected to be disappointed with companies' CEOs, governors and managers. Obviously, not all corporate shareholders benefit from these SEO/long-term TTF initiatives. Actually, the swing traders profit at the expense of the short-term speculators.

One could argue that any kind of management should be expected to act especially in the interest of existing corporate shareholders with continued share-holding interest, since shareowners who liquidate their share-positions, actually abandon and drop-out their claims, benefits and power to control the CEOs, the governors and the managers. 
In this paper, I assume that the managers' motivation is to sell overbought equities and options in SEO/long-term TTF initiatives, to boost the pre-existing old corporate shareholder holding and to drop-out of the corporate shareowner presence in the SEO initiatives. Hence, my proposed trading plan is to investigate, control and document how SEO/long-term TTF timing is functioning within shareowners (i.e. institutions vs. non-commercial individual traders vs. speculators) and if the prepared SEO and the corporate shareholder trades are logical, steady and dependable with the assumption that SEO/long-term TTF timing profits the issuing company's old corporate shareowners.

In the process to examine the functionalities of corporate share-holding at SEO, the paper categorizes corporate share-holders along with two compatible and consistent functions. First, I isolate the trading -as a long-term TTF functionality- of the old corporate shareowners (old Investors) from those investors that open positions just on the announcement of the SEO initiative (new Investors). Then, I further isolate old shareowners that continue to hold their securities and after the SEO announcement \& the SEO actual timing from those shareowners that liquidate their positions around or about the time of the SEO itself (short-term TTF functionality). In this paper, I follow Gaspar et al. (2005), as well as Yan and Zhang (2009) in order to categorize corporate investors according to their short or long position, investment and trading attitude.

With respect to the fact that the corporate shareowners seem to be found in the basis of both the pragmatic and speculative options, in the current paper I also separate corporate investors that are more possible to control and discipline from those investors (traders, speculators) that are not. Economics and finance literature proposes that some corporate investors control, plan and invest for the long run; whereas others (traders and speculators) focuses their skills on spotting on undervalues and then trade heavily to profit from their informational convenience asset positions.

It is also found that trading behavior of corporate investors at SEO/long-term \& short-term TTF suggests and denotes that such as traders, in a large scale, boost their share-holdings just before or at the time of the SEO. $I$ Furthermore, I discover no evidence that these increases take into consideration the Table 3's SEO pattern-targets (i.e. no TTF functionality is detected). These SEO pattern-targets are valid for both groups of corporate shareowners (i.e. for both: institutions with long and institutions with short investment horizons). Finally, the results show that firms with higher corporate share-holdings are in favor to employ less time from their SEOs.

The above conclusion is further supported by my findings that SEO/long-term TTF timing does not transfer wealth (profit) from the SEO swing-trading temporal investors and speculators to the old shareowners (passive-trading institutions). Explicitly, I also find (from the 2000-2016 Barron's data sources analyzed) that the companies decide the SEO initiative when the share prices are relatively high. These results signify and suggest that SEO/TTF timing does not, normally, offer benefit to long-term corporate and short-term non-commercial shareowners.

As long as the corporate swing-trading shareholders purchase shares in SEO and hence, they cannot discipline the CEO \& the managers, the results further imply that the timing of SEOs is unlikely to be impulsive (catalyst functionality) by the intention of trading overbought equities, options, futures and Forex pairs.

Paper contributes to corporate finance literature by: (a) the introduction and documentation of the innovative term "temporal (timing) trading functionality" (TTF) as a $2^{\text {nd }}$ level timing function of the casing SEO function; and (b) the executive application in SEO initiatives as technical market anomalies: (i) the long-term TTF functionalities (design a trading strategy for long/short positions at a particular period, according to candlestick patterns, like "bullish engulfing", "hammer:morning star", and "inverted hammer: evening star", as well as to price action patterns, like "cups", "uprising triangles", and "head \& shoulders / neckline"); and (ii) the short-term TTF functionalities (apply swing \& intraday time-based trading strategies for open/close positions at a particular time during the daily trading session: 09:30 am - 04:00 pm EST, according to the "price action Jesse Livermore's resistance/support pivotal-lines breakout/breakdown" confirmation/triggering signal).

The SEOs were discussed under the TTF prism for four categories of shareowners: The long-term institution \& non-commercial traders (investors), the swing momentary institution traders (institutions), the short-term non-commercial traders (speculators) and the intraday non-commercial traders (speculators).

The data analysis applied in this paper, demonstrated that swing momentary institution traders (institutions) and insiders (CEO, Governors, Officers, etc.) increase their share share-holding just before or at the announcement of the Seasoned Equity Offerings and they gain benefit at the expense of short-term and intraday non-commercial speculators, while the long-term institution and non-commercial investors' wealth position is not affected significantly by these SEO offerings (accepted standard deviation prices). 


\section{Acknowledgments}

The financial support (covering the CoT/CFTC and the Barron's \& WSJ.com market data expenses) from the EU/LLP Programme "EPOCHE 2013" (with Project No. 2012-1-GR-ERA10-10609) is gratefully acknowledged.

\section{Conflict of Interests}

The author has not declared any conflict of interests.

\section{References}

Alti, A., \& Sulaeman, J. (2012). When do high stock returns Trigger Equity Issues? Journal of Financial Economics, 103, 61-87. http://dx.doi.org/10.1016/j.jfineco.2011.08.007

Baker, M., \& Wurgler, J. (2002). Market Timing and Capital Structure. The Journal of Finance, 57, 1-32. http://dx.doi.org/10.1111/1540-6261.00414

Baker, M., Stein, J. C., \& Wurgler, J. (2003). When does the Market Matter? Stock Prices and the Investment of Equity-dependent Firms. The Quarterly Journal of Economics, 118, 969-1005. http://dx.doi.org/10.1162/00335530360698478

Barron's Financial Investment News and Market Data. (2016). Retrieved from http://www.barrons.com/data; and http://www.wsj.com; and http://www.wsj.com/europe

Basdekidou, V. A. (2015). Functionality, Returns and Efficiency before and after the Debt Crisis: An Empirical Analysis of the Greek Stock Market (Unpublished doctoral dissertation). Bulgarian Academy of Sciences Economic Research Institute, Bulgaria.

Basdekidou, V. A. (2016a). IPO Trading with Short-term and Intraday Temporal Functionalities. Business and Economics Journal, 7(4). http://dx.doi.org/10.4172/2151-6219.1000257

Basdekidou, V. A. (2016b). Personalized Temporal Trading Functionalities Engaged in Calendar Market Anomalies: Empirical Evidences from the 2007 and 2009 Financial Crises. Journal of Business \& Financial Affairs, 5(4). http://dx.doi.org/10.4172/2167-0234.1000225

Basdekidou, V. A., \& Styliadou, A. A. (2017). Technical Market Anomalies: Leveraged ETF Trading with Daily and Intraday Temporal Functionalities. Business and Economics Journal, 8(1). http://dx.doi.org/10.4172/2151-6219.1000275

Cesari, A. D., Espenlaub, S., Khurshed, A., \& Simkovic, M. (2012). The Effects of Ownership and Stock Liquidity on the Timing of Repurchase Transactions. Journal of Corporate Finance, 18, 1023-1050. http://dx.doi.org/10.1016/j.jcorpfin.2012.06.004

Chemmanur, T. J., He, S., \& Hu, G. (2009). The role of Iinstitutional Investors in Seasoned Equity Offerings. Journal of Financial Economics, 94, 384-411. http://dx.doi.org/10.1016/j.jfineco.2008.12.011

Chen, X., Harford, J., \& Li, K. (2007). Monitoring: Which institutions matter? Journal of Financial Economics, 86, 279-305. http://dx.doi.org/10.1016/j.jfineco.2006.09.005

Choie, K. S. (2016). Factors of IPO Underpricing. International Journal of Economics and Finance, 8(2), 107-114. http://dx.doi.org/10.5539/ijef.v8n2p107

Demiralp, I., D’Mello, R., Schlingemann, F. P., \& Subramaniam, V. (2011). Are there Monitoring Benefits to Institutional Ownership? Evidence from Seasoned Equity Offerings. Journal of Corporate Finance, 17, 1340-1359. http://dx.doi.org/10.1016/j.jcorpfin.2011.07.002

Edelen, R. M., Ince, O., \& Kadlec, G. B. (2015). Institutional Investors and Stock Return Anomalies. E- Journal SSRN. http://dx.doi.org/10.2139/ssrn.2359744

Gaspar, J. M., Massa, M., \& Matos, P. (2005). Shareholder Investment Horizons and the Market for Corporate Control. Journal of Financial Economics, 76, 135-165. http://dx.doi.org/10.1016/j.jfineco.2004.10.002

Gibson, S., Safieddine, A., \& Sonti, R. (2004). Smart investments by smart money: Evidence from seasoned $\begin{array}{lllll}\text { equity offerings. Journal of Financial Economics, } & \text { 72, 581-604. }\end{array}$ http://dx.doi.org/10.1016/j.jfineco.2003.05.001

Hao, G. Q. (2014). Institutional shareholder investment horizons and seasoned equity offerings. Financial Management, 43, 87-111. http://dx.doi.org/10.1111/fima.12038

Hartzell, J. C., \& Starks, L. T. (2003). Institutional Investors and Executive Compensation. Journal of Finance, 58, 2351-2374. http://dx.doi.org/10.1046/j.1540-6261.2003.00608.x 
Hovakimian, A., \& Hu, H. (2016). Institutional Shareholders and SEO Market Timing. Journal of Corporate Finance, 36, 1-14. http://dx.doi.org/10.1016/j.jcorpfin.2015.09.009

Jensen, M. C. (1986). Agency Cost of free cash flow, Corporate Finance, and Takeovers. The American Economic Review, 76, 323-329. http://www.jstor.org/stable/1818789

Markoulis, S. N., \& Neofytou, N. (2016). An Empirical Analysis of the Relationship between Oil Prices and Stock Markets. International Journal of Economics and Finance, 8(12), 120-131. http://dx.doi.org/10.5539/ijef.v8n12p120

Myers, S. C., \& Majluf, N. S. (1984). Corporate Financing and Investment Decisions when Firms have information that Investors do not have. Journal of Financial Economics, 13, 187-221. http://dx.doi.org/10.1016/0304-405X(84)90023-0

Nguyen, X. M., \& Tran, Q. T. (2016). Dividend Smoothing and Signaling Under the Impact of the Global Financial Crisis: A Comparison of US and Southeast Asian Markets. International Journal of Economics and Finance, 8(11), 118-123. http://dx.doi.org/10.5539/ijef.v8n11p118

Nickerson, D. (2016). Asset Price Volatility, Credit Rationing and Rational Lending Discimination. International Journal of Economics and Finance, 8(10), 140-158. http://dx.doi.org/10.5539/ijef.v8n10p140

Ogden, J. P., \& Wu, S. (2013). Reassessing the Effect of Growth Options on Leverage. Journal of Corporate Finance, 23, 182-195. http://dx.doi.org/10.1016/j.jcorpfin.2013.08.008

Styliadis, A. D. (2007). E-learning Documentation of Historical Living Systems with 3-d Modeling Functionality. Informatica, 18(3), 419-446. Retrieved from http://www.mii.vu.lt/informatica/pdf/INFO686.pdf

Styliadis, A. D., \& Vassilakopoulos, M. G. (2005). A Spatio-Temporal Geometry-based Model for Digital Documentation of Historical Living Systems. Information \& Management, 42(2), 349-359. http://dx.doi.org/10.1016/j.im.2004.01.006

Yan, X., \& Zhang, Z. (2009). Institutional Investors and Equity Returns: Are Short-term Institutions Better Informed? The Review of Financial Studies, 22, 893-924. http://dx.doi.org/10.1093/revfin/hhl046

\section{Copyrights}

Copyright for this article is retained by the author(s), with first publication rights granted to the journal.

This is an open-access article distributed under the terms and conditions of the Creative Commons Attribution license (http://creativecommons.org/licenses/by/4.0/). 